Права людини в Україні та у зарубіжних країнах:

проблеми теорії та нормативно-правової регламентації

DOI https://doi.org/10.36059/978-966-397-210-7/45-66

\author{
Васильченко О. П., \\ доктор юридичних наук, професор, \\ професор кафедри конституційного права \\ юридичного факультету \\ Київського національного університету \\ імені Тараса Шевченка, \\ м. Київ
}

Mamam A. B., аспірант кафедри конституційного права юридичного факультету Київського національного університету імені Тараса Шевченка, м. Київ

\title{
КОНСТИТУЦЙНІ ПРАВА ЛЮДИНИ: ЗМІСТ, ФУНКЦІЇ ТА РАМКИ ОБМЕЖЕННЯ
}

Анотація. Уроботі досліджується концепція прав людини, а також аналізується значення конституційних прав людини. Співставлено поняття «конституційні права людини», «основні права людини» та «фундаментальні права людини». Розглянуто функції прав людини та визначено функціональні особливості таких прав. Досліджено функції конституційних (основних) прав за матеріалами німецької правничої доктрини, до яких належить: оборонна функція, функція надання благ та захисту, функція однакового поводження. Розглянуто теоретичні та практичні підходи до обмеження прав людини і втручання у приватну автономію особи. Проаналізовано західні стандарти, за якими досліджується допустимість обмеження прав людини. Розглянуто деякі приклади захисту Конституційним Судом України конституційних прав людини від неконституційного їх обмеження. Наведено аналіз впроваджених карантинних заходів у зв'язку із пандемією коронавірусу (COVID-19) та правомірності обмежень конституційних прав людини в Україні. 
Права людини в Україні та у зарубіжних країнах:

проблеми теорії та нормативно-правової регламентації

\section{Вступ}

Дослідження прав людини завжди привертають увагу представників різних галузей знань, а також $є$ актуальною проблемою, яка загалом постійно розвивається та уособлює спільну ціннісну орієнтацією для сучасного світу. Залежно від різних умов (історичних, соціальних, економічних тощо) кожна окрема демократична держава має свій рівень гарантій та захисту прав людини. Проте виклики, з якими стикаються держави в умовах демократії, завжди мають дилему: як вирішити ту чи іншу проблему, не порушуючи при цьому права людини.

Сьогоднішні реалії глобального світу стали такою проблемою як для демократій зокрема, так і для сучасного світу загалом. Права людини не $є$ статичним терміном, який вивчають різні галузі знань, оскільки права людини виступають реальною та динамічною категорією. Із розвитком суспільства права людини набувають відповідно ширших характеристик, що, з одного боку наповнюють їх універсальним змістом, а 3 іншого ускладнюють їх практику реалізації.

Від таких загальних вступних тез можемо перейти до більш точкової проблеми в рамках представленої теми значення конституційних прав людини, їх функції та рамки обмеження.

Запропонована проблематика актуалізується сучасними обставинами, в яких перебувають держави у зв'язку із визнанням Всесвітньою організацією охорони здоров'я пандемії коронавірусної інфекції (COVID-19) [1] та запровадженням карантинних обмежень у світі. Такі обставини стали неабияким викликом для демократичних держав, які запроваджують різного рівня карантинні заходи, а тому підсилюють актуальність питання про обмеження конституційних прав у надзвичайних умовах.

Тема прав людини 3 різних точок зору правничих досліджень, зрозуміло, представлена у більшості наукових праць. Можемо виділити тих науковців, дослідження яких 
стали об’єктом нашої уваги, зокрема: І. Дахова, М. Козюбра, С. Максимов, М. Орзіх, П. Рабінович, С. Рабінович, В. Речицький, М. Савчин, Н. Сатохіна, О. Уварова, С. Шевчук та інші.

Питання функцій прав людини та окремо питання обмеження прав також становлять неабиякий інтерес у дослідників різних галузей права. До слова, обмеження прав людини є однією із складних проблем зі сфери прав людини, оскільки обмеження $\epsilon$ допустимими для прав людини у визначених випадках, проте не усі такі обмеження можуть вважатися правомірними.

Названа проблематика включає в себе не лише теоретичні підходи, які можна знайти у правничій доктрині, а також $є$ проблемою практичного рівня, яка потребує відповідних законодавчих гарантій та належного судового захисту у випадках неправомірного обмеження прав людини.

Як уже було сказано вище, тематика прав людини набуває нових штрихів для наукових розвідок, посилаючись на світовий карантин, викликаний поширенням пандемії коронавірусну (COVID-19). Так, більшість карантинних заходів $є$ прямим обмеженням саме конституційних прав людини, що потребує проведення відповідного наукового дослідження для виявлення та запобігання можливих проблем зі сфери прав людини у майбутньому.

Таким чином, у рамках запропонованої проблематики ми розглянемо деякі аспекти теоретичного обгрунтування конституційних прав людини, 3'ясуємо їх функціональні особливості та визначимо рамки обмеження. Наперед зауважимо, що окреслений вектор дослідження $\epsilon$ дискусійною та складною темою сьогодні, а тому 3 об'єктивних причин ми не зможемо обхопити увесь обсяг питань, оскільки для цього ще знадобиться певний час. Разом 3 тим можемо брати ту інформацію, яка $\epsilon$ у відкритому доступі та піддається науковому аналізу i дискусії. 
Права людини в Україні та у зарубіжних країнах:

проблеми теорії та нормативно-правової регламентації

\section{1. Загальнотеоретична характеристика конституційних прав людини}

Права людини як концепція, що включає у себе різні філософські та правові засади, $є$ багатоаспектним явищем. Не обмежуючись винятково правничою доктриною, права людини намагаються визначити у різний спосіб, проте єдиного їх визначення все ж знайти не вдається.

Говорячи загалом про термінопоняття «права людини», слід розуміти, що виклики XX століття стали однією із найбільш проблемних та складних для формування каталогу прав людини в наші дні. Так, за висловленням американського історика Т. Снайдера, який написав кину «Про тиранію: 20 уроків XX століття» [2], минуле століття було найбільш жорстоким у контексті прав людини, а разом з тим - саме у XX столітті каталог людських прав почав фундаментально закріплюватись на міжнародному рівні. На все це найбільше вплинула Друга світова війна, яка показала усі жахливі наслідки нелюдського поводження, геноциду та масового знищення для людства.

Проте, на жаль, ми не можемо стверджувати, що XXI століття не має загрозливих наслідків для прав людини. Навіть при тому, що, як уже було зазначено, розуміння прав людини навіть на рівні доктринальних підходів має різні варіанти.

Звернемо увагу на деякі загальнотеоретичні дані, які допоможуть розкрити зміст прав людини в рамках правничої науки.

Як випливає із аналізу філософської думки, підходи до розуміння прав людини залежать від багатьох чинників цивілізаційних, ідеологічних, політичних, соціокультурних, етичних, етноправових, та їх взаємовідносин з правом. Досі точаться дискусії (особливо серед філософів) щодо того, що собою становлять права людини - моральну чи юридичну категорію, яке їх співвідношення з державою: передують вони їхньому визнанню державою чи стають правами людини лише внаслідок їх визнання нею; в яких формах 
таке визнання відбувається; чи існують універсально значущі, загальновизнані права людини тощо [3, с. 49].

Як зазначає Н. Сатохіна у своєму дослідженні про обгрунтування прав людини, «права людини як суб'єктивні права людської істоти вперше отримують метафізичне обгрунтування у християнстві: оскільки кожна людина має душу, пов'язану 3 Богом, кожна людина $\epsilon$ носієм абсолютної цінності - людської гідності, яка і $\epsilon$ підставою наявності в людини священних та невідчужуваних прав. У Новий час права обгрунтовуються вже не тим, що всі люди створені «за образом і подобою божою», а самою природою людей, зокрема розумною природою» [4, с. 121].

Водночас у західних підходах до розуміння прав людини $\epsilon$ давньогрецький поліс. Відповідно до цієї концепції людина - це самостійний індивід, наділений не просто розумом, а свободою вибору і здатністю самостійно визначати свою долю, тобто індивідуалістично. Останнім часом на європейському континенті помітна тенденція до відмови від нав'язування жорсткого європоцентризму в розумінні прав людини та забезпечення збалансованості між правами особистості та публічними інтересами, зокрема інтересами держави [3, с. 50].

За визначенням Р. Алекзі, категорія «права людини» включає п'ять ознак, які складають її зміст. Так, на думку дослідника, «по-перше, вони застосовуються універсально, тобто носієм цих прав $\epsilon$ кожна людина. Право на життя зобов'язує кожного поважати це право, тобто кожну людину, а також держави і організації. Винятком із загального підходу $\epsilon$ право на участь у політичному прийнятті рішень: це право належить винятково громадянам держави, які $\epsilon$ власниками цього права» $[5$, c. 16$]$.

Підсумовуючи вивчення прав людини, автори підручника загальної теорії права за редакцією М. Козюбри дійшли висновку про те, що «права людини - це визнані світовим співтовариством блага й умови життя, яких може домагатися особа від держави і суспільства, в яких вона 
живе, та забезпечення яких реальне в умовах досягнутого людством прогресу» [3, с. 50].

Таким чином, на нашу думку, права людини стали ціннісним орієнтиром для цивілізованого світу, який у сучасних умовах не може розвиватись без прав людини. Водночас сфера прав людини утвердилась не лише як загальнотеоретична концепція, а також сформувалась на рівні відповідного правового статусу. Тому далі буде йтися про конституційну регламентацію прав людини.

Слід відзначити, що зміст прав людини складає відповідна класифікація таких прав. Серед іншого, сьогодні права людини гарантуються на рівні конституцій, конституційних актів та міжнародно-правових документів. Таким чином, права людини називають конституційними, фундаментальними, основними тощо. Взаємозумовленість та взаємозалежність термінів конституційні, основні та фундаментальні права людини продемонструємо далі.

У теорії конституційного права правам людини приділяється окрема увага. Оскільки права людини є інститутом конституційного права багатьох держав зазвичай підходи до конституційних прав людини базуються на інтеграції двох основних напрямів юридичної теорії: природно-правового та позитивістського. Природноправові теорії розглядають людину як істоту, яка має невіддільні від ії̈ буття права, що випливають або 3 розуму, або з божественної волі, або з природи людини. Позитивістські ж теорії підходять до прав людини як до категорії, що встановлюється державою. Поєднання цих двох напрямів практично здійснюється шляхом прийняття конкретних конституційних положень або «Білля про права». Тому права людини набувають юридичної форми і стають одним із важливих інститутів конституційного права [6, с. 17].

Здебільшого фундаментальні права людини визнаються державами безпосередньо діючим правом. При цьому неважливо, мають вони відповідне закріплення в законах чи ні. Існують країни, в яких права людини законодавчо не 
зафіксовані, проте це не позбавляє кожну людину права не бути підданою катуванню, довільно заарештованою, неправомірно обмеженою в свободі слова тощо. Навпаки, це означає, що закріплення прав людини у конституціях та законах - важливий, але часто не визначальний крок для їх визнання державами. Все залежить від рівня забезпеченості прав людини, зокрема від розвинутості юридичних засобів і процедур їх реалізації та захисту $[3$, c. 52].

Порівнюючи фундаментальні права 3 основними правами, слід звернутися до німецької доктрини, оскільки за таким підходом конституційними правами $\epsilon$ основні права на підставі Основного Закону ФРН.

Так, А. Вільдтом, порівнюючи фундаментальні права 3 основними правами людини, зазначає про те, що «ідея фундаментальних прав або «основних прав» $\epsilon$ нині двозначною. По-перше, її можна тлумачити таким чином, що ці права $\epsilon$ найзагальнішими правами, за допомогою яких обгрунтовуються чи легітимізуються спеціальні права. Цей аспект виходить на передній план передусім тоді, коли наголошують на універсальності прав людини. По-друге, під «фундаментальними» правами мають на увазі також найважливіші за змістом права, тобто принаймні інваріантне ядро мінімальних прав. Цей аспект виходить на передній план тоді, коли виявляється недоторканність та невіддільність прав людини» [7, с. 119].

Можна зробити узагальнення про те, що ідея основних прав за німецькою доктриною має достатньо спільного 3 концепцією фундаментальних прав, яка втілена у Загальній декларації прав людини та, пізніше, у Конвенції про захист прав людини і основоположних свобод. Таким чином, сформовано беззаперечну ідею про те, що права людини уособлюють собою цінність у глобальному сенсі.

Основний Закон ФРН, який було прийнято 23 травня 1949 року, закріплює перелік основних прав, тобто конституційно гарантованих прав людини, у Розділі I «Основні права», який включає 22 статті (разом 3 
поправками). Так, серед основних прав за Основним Законом ФРН можна виділити такі: захист людської гідності (ст. 1), особиста свобода (ст. 2), рівність перед законом (ст. 3), свобода віри, совісті та віросповідання (ст. 4), свобода вираження поглядів (ст. 5), а також інші [8].

Між тим, в американському конституціоналізмі, як зазначає М. Антонович, не йдеться про правовий статус індивіда як сукупність його прав та обов'язків. Навпаки, постійно підкреслюється, що це сам індивід наділив державу правом і обов'язком контролювати, аби його невіддільні права не порушувались. 3 посиланням на Л. Хенкін вказується, що Конституція США не створює, не встановлює і не дарує права. Вона тільки передбачає, що вже наявні права повинні поважатись урядом. Одна 3 причин того, чому Конституція США спочатку не включала Білля про права, полягала в тому, що ії творці не бачили необхідності захищати права людей, які вже існували, від нового федерального уряду [6, с. 17-18].

Розглядаючи особливості визначення конституційного рівня прав людини в Україні, слід звернути увагу на те, що статтею 22 (1) Конституції України закріплено: «Права і свободи людини і громадянина, закріплені цією Конституцією, не $є$ вичерпними». Разом з тим за статтею 22 (3) визначено, що «При прийнятті нових законів або внесенні змін до чинних законів не допускається звуження змісту та обсягу існуючих прав і свобод». Такий підхід загалом дає підстави зробити висновок про те, що конституційні права людини не обмежені лише текстом Конституції України, а тому мають безпосередній зв'язок із тими гарантіями, які регулюються поточним законодавством, для якого конституційні права людини $є$ джерелом. До слова, за Конституцією України можна виділити перелік прав людини, він $\epsilon$ узгодженим із міжнародними засадами каталогу таких прав. Водночас те чи інше конституційне право людини здебільшого знаходить більш детальний зміст у поточному 
законодавстві (наприклад, право на працю чи відпочинок в нормах трудового законодавства і так далі).

Для аргументації такого твердження наведемо думку М. Савчина, який вказує на те, що «сьогодні посилюється горизонтальний ефект конституцій, згідно 3 яким фундаментальні права людини визначають зміст поточного законодавства, неприпустимість свавільного застосування законодавства, що призводить до посягання сутнісного змісту фундаментального права людини» $[9$, c. 243].

\section{2. Функціональні особливості конституційних прав людини}

Досі залишається поза увагою серед й без того великої кількості наукових досліджень у сфері прав людини питання їх (прав людини) функцій та функціонального призначення. Вивчення проблематики функцій основних прав, а також з'ясування функціонального призначення таких прав є метою представленої статті.

Свого часу Г. Ярас вказував у своєму дослідженні на те, що «коли йдеться про «функції основних прав», то природним $\epsilon$ питання про те, до якого виду належать впливи і юридичні наслідки, що виникають із основних прав. На перший план виступає їхня оборонна функція, що змушує державу утримуватися від певних дій» [10, с. 626].

Водночас широта досліджень прав людини, яка сьогодні представлена у різних напрямах суспільних наук, а найбільше - у правничій науці, набуває всезагального значення як цілісна концепція в сучасних умовах розвитку права, суспільства та держави. Особливе значення мають права людини, які все ще розвиваються та наповнюються новітнім змістом, на який впливають різноманітні фактори: економічні, політичні, соціальні, екологічні тощо.

Права людини в умовах демократії - це також критерії, за якими можна здійснити замір якісних та кількісних показників розвиненості держави. Тому вважаємо, що окремої уваги потребує дослідження функцій прав людини, 
вивчення яких дасть можливість комплексно визначити особливості практики реалізації прав людини. Зазначена теза також підтверджується необхідністю у пошуку нового фокусу досліджень прав людини, зважаючи на перспективи європейської та євроатлантичної інтеграцї̈ України.

Тому пропонуємо розглянути функції конституційних (онсовних) прав людини та з'ясувати їх сутнісне значення.

Перш за все важливо почати 3 питання про те, яку функціональну роль відіграє право як явище соціальної дійсності. До прикладу, на думку авторів Великої української юридичної енциклопедії, «функціональна роль права полягає в тому, що воно виражає загальнолюдські інтереси, певні соціальні прагнення, волю більшості громадян, визначає права, свободи і обов'язки громадян» [11, с. 627].

Взаємозв'язок функціонального призначення права та прав людини можемо пояснити тим, що права людини $\epsilon$ ціннісною орієнтацією для права та суспільних відносин, які покликане регулювати право в сучасних умовах розвитку. Проте сьогодні все ще малодослідженим в українській правничій науці залишається проблема функцій прав людини, яка може розвивати вивчення функцій права.

Передумовою для змістовного дослідження функцій прав людини, видаються цікавими дослідження, які торкаються проблеми обгрунтування прав людини, як це представлено в однойменній публікації Н. Сатохіної. Так, звертається увага на те, що, «незважаючи на широке визнання ідеї прав людини в усьому світі, ці питання не $є$ ані простими, ані риторичними. Ба більше, обгрунтування прав людини сьогодні $є$ не лише ключовою, а й найбільш контроверсійною проблемою філософії прав людини» [4, с. 119].

На переконання Ю. Размєтаєвої, права людини містять ідею гідності, поваги і до інших, і до себе, тому вони деякою мірою виховують людину. Дослідниця також зазначає, що існування громадянського типу суспільства, його формування неможливе без появи нових суспільних індивідів - громадян, які мають рівні права і своєрідні громадянські якості [12, с. 71]. 
Зрештою, функції прав людини - це більшою мірою філософська концепція, крізь приму відповідних методів дослідження ця концепція може бути детально вивченою та обгрунтованою. Завданням правничих досліджень залишається фокус на правах людини загалом, але хаотичні та загальні дослідження з теми прав людини певною мірою заплутують зміст проблематики, що своєю чергою не дає зрозуміти чіткість у вивченні прав людини, зокрема в сучасних умовах розвитку України.

$\mathrm{У}$ цієї проблеми $\epsilon$ щонайменше два пояснення: по-перше, це розуміння прав людини в соціальному (або навіть соціалістичному) контексті, що в загальних рисах позиціонує права людини як соціальні очікування громадян від держави. Це зрозуміло у зв'язку з тим, що тривалий час Україна перебувала під гнітом тоталітарного режиму. Та, по-друге, що логічно пов'язано із першою причиною, це нерозуміння прав людини як фундаментальної цінності в умовах демократії. Для цього важливе значення має переосмислення розуміння ідеї прав людини.

Таким чином, розуміння прав людини - це пряма вказівка на те, що можна включати у визначення поняття функцій прав людини. Зрозуміло, що починати потрібно 3 кореневої проблеми, суть якої окреслено вище. Разом 3 тим, як було зазначено, пошук відповідей на питання про функції прав людини знаходиться у дослідженнях, присвячених філософії права.

Як нами було зазначено на початку, німецький дослідник Г. Ярас, досліджуючи функції основних прав у німецькій доктрині, виділяв серед таких функцій дещо інші, а саме: оборонну функцію, функцію надання благ та захисту, функцію однакового поводження [10, с. 626].

Однією із ключових функцій основних прав, на думку Г.Яраса, слід вважати оборонну. Отже, оборонна функція основних прав дослідником пояснюється на конкретному прикладі: «якщо комусь не дадуть найняти адвоката для захисту і реалізації своїх прав у стосунках з виконавчою владою, слід згадати про оборонну функцію, присутню 
в абзаці четвертому статті 19 Основного Закону Німеччини, яка так само гарантується цим основним правом». Звертають на себе увагу простори можливостей, які в сфері вторинної оборонної функції прав на блага $\epsilon$ значно вужчими, ніж для (первинної) функції надання благ [10, с. 645].

Розглядаючи наступну функцію - надання благ та захисту, Г. Ярас резюмує, що частково функцію захисту розглядають як незалежну, окрему функцію, а всі інші змісти охоплюються поняттям функції надання благ. Обов'язок надавати захист стосується також зобов'язання держави діяти, що існує в трикутнику між носієм основних прав, приватною третьою стороною і державою, тоді як функція надання благ має значення лише в стосунках носія основних прав і держави [10, с. 635].

Насамкінець, серед загальних функцій основних прав, німецький дослідник виділяє функцію однакового поводження. Так, з основних прав на свободи часом навіть сам Федеральний конституційний суд Німеччини виводить обов'язки однакового поводження, зокрема «заборону упослідження» (BVerfGE 105, 313 (346). Наскільки це $\epsilon$ слушним, настільки основним правам на свободи належить вторинна функція - функція однакового поводження або «функція недискримінації» (Jarass. Bausteine (Bibl.). Проте функцію однакового поводження нерідко і за різних умов розуміють як вираження оборонної функції [10, с. 641].

Крім того, як йдеться 3 цього приводу у дослідженні Г.Яраса, Федеральний конституційний суд частково поєднав обов'язки однакового поводження з об'єктивним змістом пов'язаних 3 ними основних прав (VerfGE 80, 124 (133f.); однак об’єктивний зміст відповідних прав сам по собі $\epsilon$ протиставленням, антагонізмом оборонної функції. Разом із тим випадки таких обов'язків однакового поводження зустрічаються нечасто. До того ж чимало конкуруючих спеціальних основних прав рівності мають пріоритет [10, с. 641]. 


\section{3. Рамки обмеження конституційних прав людини}

Розглянувши права людини на рівні конституційної регламентації та дослідивши функціональні особливості права людини, про які лише частково згадується в доктрині, слід перейти до завершальної частини цієї наукової розвідки - рамки обмеження конституційних прав людини.

Наголосимо, що питання обмеження прав людини окрема складна проблематика, оскільки права людини здебільшого не $\epsilon$ абсолютними, а тому можуть обмежуватись. Разом 3 тим такі обмеження мають відповідні межі, про що йтиметься далі.

Як зазначає О. Панкевич у контексті цієї проблеми, «обмеження основних прав $\epsilon$ фундаментальною (базовою) категорією конституційно-правового статусу особи. 3 огляду на те, що абсолютних, «безмежних» прав людини апріорі існувати не може, вважаємо встановлення чітких та зрозумілих критеріїв обмежування таких прав на найвищих (міжнародно-правовому та конституційному) рівнях важливою гарантією від можливих дій держави та її окремих органів щодо свавільного зменшення обсягу правореалізації» [13, с. 146-147].

Як вже було зазначено вище, права людини не слід вважати абсолютними. Тому складність питання обмеження конституційних прав людини полягає в тому, що держава має утримуватися від надмірного втручання у приватну сферу індивіда, але понад тим - будь-яке втручання має бути обгрунтованим, а саме відповідати легітимній меті та бути пропорційним. Загалом конституційний принцип пропорційності відіграє вирішальну роль у контексті обгрунтованості обмеження прав людини.

Досліджуючи обмеження прав i свобод людини, М. Савчин розкриває значення проблеми втручання так: «втручання публічної влади у сферу приватної автономії індивіда виключно на підставі закону, яким запроваджуються певні заходи, спрямовані на забезпечення балансу приватних і публічних інтересів з метою захисту 
національної безпеки, громадського порядку, життя i здоров'я інших людей, авторитету правосуддя» [14, с. 291].

Слід додати, що обмеження конституційних прав людини мають бути тимчасовим необхідним заходом. Так, на думку I. Дахової, «обмеження щодо реалізації прав i свобод людини - це передбачений законом захід тимчасового характеру, що застосовується до особи 3 боку держави». Разом з тим, на думку вченої, для правомірності державного втручання у право людини необхідно, щоб таке втручання здійснювалось задля досягнення легітимної мети, якою завжди є захист певних суспільних або державних цінностей, та була необхідною в демократичному суспільстві [15, с. 22].

Щоб повною мірою визначити, чи не виходить за межі держава під час втручання у права людини, для цього мають бути визначені рамки, які відповідають усталеним міжнародним стандартам. Загалом, за «сучасними європейськими стандартами, до таких належать:

- обмеження мають встановлюватися винятково законами;

- бути пропорційними до визначеної конституцією i законами мети;

- обгрунтовані публічними інтересами, необхідними для нормального функціонування демократичного суспільства, або захистом прав інших людей;

- будь-які обмеження прав мають застосовуватися лише у тому разі, якщо не існує інших, менш обтяжливих заходів досягнення мети забезпечення публічних інтересів, прав інших осіб;

- наслідки обмежень прав не повинні бути надмірними;

- обмеження не повинні спотворювати суть обмежуваних прав» [3, с. 60].

Таким чином, стандартом для визначення допустимих меж втручання у права людини слід вважати вироблений Європейським судом 3 прав людини так званий «трискладовий текст», за яким аналізується наявність 
обмеження прав, яке: 1) має бути передбачене законом 2) повинно мати легітимну мету 3) повинно мати необхідність обмеження в демократичному суспільстві. Цей уніфікований підхід до розуміння принципу пропорційності в конституційному праві став класичним.

За Конституцією України, конституційні права людини не можуть бути обмежені, окрім тих випадків, які передбачені Конституцією. Так, статтею 64 (2) визначено перелік конституційних прав і людини, які не можуть бути обмеженими: «В умовах воєнного або надзвичайного стану можуть встановлюватися окремі обмеження прав і свобод із зазначенням строку дії цих обмежень. Не можуть бути обмежені права і свободи, передбачені статтями 24, 25, 27, $28,29,40,47,51,52,55,56,57,58,59,60,61,62,63$ цієї Конституції».

Таким чином, встановлено, що не підлягають обмеженню рівність прав і свобод, право на життя, право на повагу до гідності, право на свободу і особисту недоторканність, право на звернення до органів державної влади та органів місцевого самоврядування, право на житло, право на шлюб, право на судовий захист, право на професійну правничу допомогу тощо.

Щодо обмеження конституційних прав людини, то тут також вбачається за доцільне звернутися до практики Конституційного Суду України, який визнавав неконституційними ті закони, які надмірно обмежували конституційні права людини.

Рішенням Конституційного Суду України від 29 грудня 1999 року № 11-рп/1999 було захищено конституційне право людини на життя та визнано існування смертної кари як виду покарання - неконституційним. Зокрема, Суд дійшов висновку про те, що «Конституція України не містить будь-яких положень про можливість застосування смертної кари як винятку з положення частини першої статті 27 Конституції України про невіддільне право на життя кожної людини. Таким чином, смертну кару як вид покарання, передбачений у відповідних положеннях 
Права людини в Україні та у зарубіжних країнах:

проблеми теорії та нормативно-правової регламентації

Кримінального кодексу України, не можна вважати винятком з невіддільного права на життя кожної людини, закріпленого у Конституції України. Положення Кримінального кодексу України щодо застосування смертної кари як виду покарання повинні розглядатись як не передбачені Конституцією України обмеження невіддільного права на життя кожної людини і мають бути визнані такими, що не відповідають Конституції України (неконституційними)» [16].

Вирішуючи питання про конституційність у справі про призначення судом більш м'якого покарання, Конституційний Суд України рішенням від 2 листопада 2004 року № 15-рп/2004 визначив, що «правова держава, вважаючи покарання передусім виправним та превентивним засобом, має використовувати не надмірні, а лише необхідні і зумовлені метою заходи. Обмеження конституційних прав обвинуваченого повинно відповідати принципу пропорційності: інтереси забезпечення охорони прав i свобод людини i громадянина, власності, громадського порядку та безпеки тощо можуть виправдати правові обмеження прав і свобод тільки в разі адекватності соціально зумовленим цілям» [17].

Крім того, принагідно навести як приклад захисту від надмірного обмеження конституційних прав рішення Конституційного Суду України від 1 червня 2016 року № 2-рп/2016 (справа про судовий контроль за госпіталізацією недієздатних осіб до психіатричного закладу).

У вказаному рішенні Суд констатував, «обмеження щодо реалізації конституційних прав і свобод не можуть бути свавільними та несправедливими, вони мають встановлюватися виключно Конституцією i законами України, переслідувати легітимну мету, бути зумовленими суспільною необхідністю досягнення цієї мети, пропорційними та обгрунтованими, у разі обмеження конституційного права або свободи законодавець зобов'язаний запровадити таке правове регулювання, яке дасть можливість оптимально досягти легітимної мети з міні- 
мальним втручанням у реалізацію цього права або свободи і не порушувати сутнісний зміст такого права» [18].

Разом 3 тим не можна сказати, що практика конституційної юрисдикції $\epsilon$ настільки грунтовною відносно захисту конституційних прав людини, щоб у державі не було місця для прикладів надмірного втручання та обмеження таких прав.

На початку дослідження ми звертали увагу на те, що демократія, для якої $є$ цінністю права людини, не може відмежуватися від непередбачуваних викликів. Сьогодні таким глобальним викликом для сучасних демократій стала пандемія коронавірусної інфекції (COVID-19). Карантин було визнано форс-мажором, проте такі заходи межують на рівні допустимих меж для обмеження конституційних прав людини. Не маємо підстав робити далекоглядні висновки щодо пропорційності обмежувальних заходів у період карантину, але маємо можливість проаналізувати деякі аспекти цієї актуальної проблеми.

Загальний екскурс запровадження карантину в Україні можна описати таким чином: карантинні заходи на загальнодержавному рівні було запроваджено рішенням Кабінету Міністрів України, а також Указом Президента України, яким було затверджено Рішення національної безпеки та оборони України «Про невідкладні заходи щодо забезпечення національної безпеки в умовах спалаху гострої респіраторної хвороби COVID-19, спричиненої коронавірусом SARS-CoV-2» від 13 березня 2020 року. Також на виконання цих рішень органами державної влади, місцевого самоврядування, підприємствами, установами та організаціями, незалежно від форм власності, приймались додаткові рішення про запровадження карантинних обмежень на локальному рівні.

Загалом запроваджено обмеження стосовно переміщення групою осіб у кількості більше ніж дві особи; відвідування парків, скверів, зон відпочинку, лісопаркових та прибережних зон, крім вигулу домашніх тварин однією особою; перебування на вулицях без документів, що 
посвідчують особу, підтверджують громадянство чи іiі спеціальний статус і так далі.

У суспільстві відбулись дискусії щодо можливості запровадження обмежень на такому рівні, без запровадження надзвичайного стану в державі. До слова, на думку експертів ГО «Центру політико-правових реформ», обмежувальні заходи, які запроваджено в Україні в березні 2020 року, суттєво обмежують конституційні права і свободи людини і громадянина, а тому вони не можуть запроваджуватися поза межами легальних правових режимів, передбачених Конституцією України. Тому правовим режимом, у межах якого допустиме обмеження конституційних прав людини, $\epsilon$ надзвичайний стан. Надзвичайний стан може вводитися для боротьби 3 пандеміями, що створюють загрозу життю і здоров'ю значних верств населення, як на території всієї України, так і в окремих її місцевостях [19].

Крім того, експерти Харківської правозахисної групи також висловили пересторогу щодо доцільності та законності запровадження карантинних заходів в Україні. На думку цієї правозахисної організації, такого роду обмеження мали запроваджуватися в рамках введення надзвичайного стану. Зазначається, що епідемія COVID-19 $є$ тяжким випробуванням для України. Водночас, незважаючи на кризові явища у суспільстві, Україна має залишатися правовою та демократичною державою. Прийняття рішень органами державної влади поза межами їх повноважень, до яких, на їхню думку, належить і рішення Кабінету Міністрів України, є неприпустимим кроком до сваволі влади та хаосу у суспільстві [20].

Отже, держава зобов'язана належним чином реагувати на виклики такого масштабу, як протидія пандемії (COVID-19). Разом з тим від того, наскільки дії держави будуть правомірними, а запровадженні обмеження пропорційними, залежить рівень розвитку як демократії, так і гарантії та захисту прав людини. 
Очевидним $\epsilon$ також той факт, що у найближчому майбутньому виникнуть спори, пов'язані із захистом прав людини в умовах карантину. До прикладу, деякі держави (Албанія, Вірменія, Естонія, Грузія, Латвія, Північна Македонія, Республіка Молдова, Румунія, Сан-Марино, Сербія $\left.{ }^{1}\right)$ заявили про відступ від зобов'язань до Конвенції про захист прав людини i основоположних свобод 1950 року (на підставі статті 15 Конвенції) у зв'язку з пандемією COVID-19.

Понад це, на думку професора Центральноєвропейського університету Дж. МакБрайда, відступ від зобов'язань не звільнить держави від відповідальності за втручання у права і свободи. «Існують сумніви в тому, чи всі накладені обмеження вимагають того, щоб відступ від зобов'язань залишався сумісним з вимогами Конвенції, але $\epsilon$ й інші, які можуть стати необхідними, особливо якщо вони триватимуть протягом тривалого періоду» [21]. Разом $з$ тим не виключено, що до Європейського суду 3 прав людини надходитимуть скарги від заявників, які обгрунтовуватимуть порушення конвенційних прав державою в умовах карантинних обмежень.

\section{Висновки}

До змісту прав людини, окрім аксіологічних засад в умовах демократії, також слід віднести поділ їх на різні групи. В рамках цього дослідження увагу приділено конституційним правам людини. У правничій доктрині часто покликаються на права людини як конституційні, основні, фундаментальні тощо. Загалом названа градація прав людини $є$ рівнем одного порядку.

Комплексне розуміння функціонального призначення прав людини, яке може розкриватись у тому числі через відповідні функції, дає можливість навести фокус на

1 За даними офіційного веб-сайту Ради Європи станом на 24 квітня 2020 року: URL: https://www.coe.int/en/web/conventions/ full-list/-/conventions/webContent/62111354 
змістовні проблеми прав людини в сучасних умовах. Загальні підходи до розуміння прав людини 3 погляду практики їх реалізації не враховують кореневі проблеми цієї теми, особливо у правничих дослідженнях.

Окрему увагу слід приділяти межам для обмеження конституційних прав людини. Такі обмеження $\epsilon$ допустимими за умови відповідності їх стандартам, виробленим західною правничою доктриною 3 прав людини. Таким чином, рамками обмеження прав людини $\epsilon$ так званий «трискладовий тест» на пропорційність: 1) правовий закон; 2) легітимна мета; 3) обгрунтована необхідність обмеження в демократичному суспільстві.

\section{Список використаних джерел:}

1. Coronavirus disease (COVID-19) Pandemic. URL: https://www.who.int/emergencies/diseases/novelcoronavirus-2019 (Дата звернення 20.04.2020).

2. Timothy D. Snyder. "On Tyranny: Twenty Lessons from the Twentieth Century". 2017, 128 p.

3. Загальна теорія права : підручник / За заг. ред. М.I. Козюбри. Київ : Ваіте, 2015. 392 с.

4. Сатохіна Н.I. Обгрунтування прав людини: реконструкція проблеми. Вісник Національного університету «Юридична академія України імені Ярослава Мудрого». Серія: Філософія. 2016. № 1. С. 119-127.

5. Robert Alexy, Menschenrechte ohne Metaphysik?, in: DZPhil 52 (2004) S. 15-24.

6. Антонович М.М. Права людини за конституційним та міжнародним правом: порівняльний аспект. Наукові записки НаУКМА. Серія «Правничі науки». 2000. Т. 18: C. $16-21$.

7. Філософія прав людини / За редакції Ш. Госепата та Г. Ломана ; пер. 3 нім. О. Юдіна та Л. Доронічевої. Київ : Ніка-Центр, 2016. 320 с.

8. Basic Law For The Federal Republic of Germany. URL: http://www.codices.coe.int/NXT/gateway.dll?f=templates\&fn= default.htm (дата звернення 21.04.2020). 
9. Савчин М.В. Конституційне право України : підручник / відп. ред. проф., д.ю.н. М.О. Баймуратов. Київ : Правова єдність, 2009. 1008 с.

10. Hans D. Jaras Funktionen und Dimensionen der Grundrechte / Handbuch der Grundrechte in Deuschland und Europa. C.F. Muller, Verlagsgruppe Huthing Jehle Rehm GmbH, Heidelberg, Munchen, Landsberg, Berlin, 2006, S. 625-654.

11. Велика українська юридична енциклопедія : Т. 2 : Філософія права / редкол. : C.I. Максимов та ін. Харків : Право, 2017. 1128 с.

12. Размєтаєва Ю.С. Права людини як фундаментальна цінність громадянського суспільства : монографія. Харків : «Финарт», 2013.196 с.

13. Панкевич 0.3. Підстави обмежування прав людини: філософсько-правовий аспект. Вісник Національної академії правових наук України. 2016. № 3. С. 141-150.

14. Савчин М.В. Сучасні тенденції конституціоналізму у контексті глобалізації та правового плюралізму : монографія. Ужгород : РІК-У, 2018. 440 с.

15. Дахова I.I. Обмеження реалізації прав і свобод людини: конституційне регулювання та практика Європейського Суду з прав людини. Форум права. 2018. № 4. C. 17-25.

16. Рішення Конституційного Суду України у справі за конституційним поданням 51 народного депутата України щодо відповідності Конституції України (конституційності) положень статей 24, 58, 59, 60, 93, 190-1 Кримінального кодексу України в частині, що передбачає смертну кару як вид покарання (справа про смертну кару) від 29 грудня 1999 року № 11-рп/1999 URL: https://zakon.rada.gov.ua/laws/show/v011p710-99 (дата звернення 24.04.2020).

17. Рішення Конституційного Суду України у справі за конституційним поданням Верховного Суду України щодо відповідності Конституції України (конституційності) положень статті 69 Кримінального кодексу України (справа про призначення судом більш м'якого покарання) 
від 2 листопада 2004 року № 15-рп/2004 URL: https://zakon.rada.gov.ua/laws/show/v015p710-04 (дата звернення 24.04.2020).

18. Рішення Конституційного Суду України у справі за конституційним поданням Уповноваженого Верховної Ради України 3 прав людини щодо відповідності Конституції України (конституційності) положенням третього речення частини першої статті 13 Закону України «Про психіатричну допомогу» (справа про судовий контроль за госпіталізацією недієздатних осіб до психіатричного закладу) від 1 червня 2016 року № 2-рп/2016 URL: https://zakon.rada.gov.ua/laws/show/ v002p 710-16 (дата звернення 24.04.2020).

19. Суттєві обмеження прав i свобод людини i громадянина $\epsilon$ неконституційними без введення надзвичайного стану / веб-сайт ГО «Центр політикоправових реформ» URL: https://pravo.org.ua/ua/news/ 20874326-suttevi-obmegeennya-prav-i-svobod-lyudini-igromadyanina-e-nekonstitutsiynimi-bez-vvedennya-nadzvichaynogo-stanu?fbclid=IwAR3KZD-qxIFL3yuWMQIOIUYp9_aXLe FuzNz2al6Fe2b8bR1MSU0Amf2_1oM (дата звернення 24.04.2020).

20. Висновок Харківської правозахисної групи щодо доцільності та законності запровадження карантинних заходів відповідно до Постанови Кабінету міністрів України № 255 від 2 квітня 2020 року / веб-сайт Харківської правозахисної групи URL: http://khpg.org/ index.php?id=1586221405 (дата звернення 24.04.2020).

21. У якій мірі боротьба 3 коронавірусною інфекцією допускає обмеження прав людини / стаття Джеремі МакБрайда на веб-сайті «Закон і Бізнес» URL: https://zib.com.ua/ua/142070-covid-19_i_konvenciya_u_yakiy_ miri_borotba_z_koronavirusnoyu.html (дата звернення 23.04.2020). 